\title{
DEVELOPMENT OF THE PERSONAL SELF-DETERMINATION OF SECONDARY SCHOOL STUDENTS IN THE CONTEXT OF THE HUMANITARIAN PARADIGM OF EDUCATION
}

\author{
Roman Alijev \\ Riga Classical Gymnasium, Latvia \\ Zoja Chehlova \\ University of Latvia, Latvia \\ Ingrida Kevisa \\ Latvian Academy of Culture, Latvia
}

\begin{abstract}
The research problem is the development of the personal self-determination of secondary school students in the process of learning based on the humanitarization of education. The research has been underpinned by the humanitarian paradigm of education, which is the result of the development of pedagogical methodology. In the $21^{\text {st }}$ century, pedagogy is viewed as a social-humanitarian science with the predominance of the humanitarian component. We regard humanitarization as a contemporary technology of the educational process. The aims of the study are to analyse the characteristics of the personal self-determination of adolescents, identify the structure of the personal self-determination of secondary school students and determine conditions for the development of the personal selfdetermination of secondary school students in the process of learning. The research methods include observation, survey, conversation, an establishing experiment, mathematical statistics. The research results:

1. there was determined the structure of personal self-determination of secondary school students as the system of inter-connected components;

2. it was established that the humanitarization of the educational process is the key precondition for the development of the personal self-determination of secondary school students both regarding the logic of the subject and the logic of the process of learning (changing the style of relationships), as well as the logic of education (understanding culture as the world of human attitudes and meanings);

3. the key values of secondary school students were identified, which were mainly pragmatic values.
\end{abstract}

Keywords: humanitarian paradigm of education, humanitarization, personal selfdetermination, values and meanings. 
Alijev et al., 2021. Development of the Personal Self-Determination of Secondary School Students in the Context of the Humanitarian Paradigm of Education

\section{Introduction}

The topicality of the research. The research was carried out on the basis of the humanitarian paradigm of education developed by Zoja Chehlova (Čehlova, 2001). The humanitarian paradigm of education is the result of the development of pedagogical methodology. In the $21^{\text {st }}$ century, pedagogy is viewed as a social and humanitarian science with the predominance of the humanitarian component. Humanitarization is regarded as a contemporary technology of the educational process. It implies focusing on the development of the content of education in order to nurture and develop an individual. Knowledge is regarded as the means of humanitarization.

The aims of the research are as follows:

- $\quad$ to analyse the essence of personal self-determination in adolescence;

- $\quad$ to determine the structure of the personal self-determination of a senior secondary school student;

- $\quad$ to identify the conditions for the development of the personal selfdetermination of secondary school students in the educational process;

- $\quad$ to conduct an establishing experiment in Riga Classical Gymnasium and in Pushkin Lyceum.

The research methods used in the study include observation, survey, experiment, and mathematical statistics.

\section{The Essence of Personal Self-determination in Adolescence}

The topicality of the problem of personal self-determination in the period of adolescence is underpinned by the need to educate a European citizen on the basis of the system of fundamental human values (Chehlova, Kevisa, Chehlov, \& Marchenoka, 2016). The relevance is also due to the development of the methodology of pedagogy (Chehlova, Chehlov, \& Gode, 2018). Pedagogy is currently viewed as a social and humanitarian science with the predominance of the humanitarian component. The humanitarian paradigm of education is a system-forming element in the pedagogical activity. As a result, the reference points of the pedagogical activity have changed:

- $\quad$ there has been a shift in educational emphasis from behavioural rules to value relationships (values are made explicit instead of analysing correct behaviour);

- the transformation of the educational paradigm of the interaction "teacher-learner" into the paradigm "person-person", where the concept of "person" is interpreted as an individual being part of humanity; 
- $\quad$ replacement of the administrative style of communication between a teacher and students with a humanistic style, which presupposes student's freedom of choice as the most important principle of their education (I suggest discussing, could you...);

- $\quad$ education is seen as the basis for individual's upbringing in culture (Alijevs, 2005).

The actualization of the humanitarian component in pedagogy has led to the study of those aspects of personality development that previously remained outside the scope of pedagogical analysis. These aspects include the construct "personal self-determination", which is the subject of research in psychology. It should be noted that until recently the issue concerning the development of selfdetermination had not been the subject of comprehensive research in the science of pedagogy. In this regard, there should be pointed out the study by M.Chehlov "The Humanitarian Basis for the Development of Personal Self-Determination of Senior Secondary School Students” (Čehlovs, 2011).

The methodological foundations for the problem of self-determination were laid by Rubinstein (1989). He considered self-determination in the context of the problem of determination; according to the principle proposed by him - external causes act by refracting through internal conditions. In this context, selfdetermination acts as internal determination in contrast to external determination. It is an important conclusion for a teacher. Thus, the concept of "selfdetermination" expresses the active nature of "internal" conditions of a person, rather than one-sided submission to external social conditions. Moreover, the specific nature of human existence, according to Rubinstein, lies in the extent of correlation between personal self-determination and determination by other social conditions, and the character of self-determination also depends on that.

In Western psychology, there is a category analogous to the concept of "personal self-determination"; namely, the category of "psycho-social identity" developed and introduced in the academic discourse by the American scholar Erik Erikson (1959). The "normative identity crisis" is the central moment through the prism of which the formation of a personality at a transitional stage is viewed, including the period of adolescence. The word "normative" has the connotation that the author views the life cycle of a person as a series of successive stages, each of which is characterised as a specific crisis in the relationships of the individual with the outside world. According to Erikson, the main task that an individual faces is the formation of the sense of identity. An adolescent has to answer the questions: "Who am I?", "What is my further path in life?” Searching for personal identity, individuals decide what actions are important for them and develop certain norms for assessing the behaviour of other people. This process is also associated with the awareness of their own value and competence. The main danger that a young person should avoid in this period, according to Erikson, 
Alijev et al., 2021. Development of the Personal Self-Determination of Secondary School Students in the Context of the Humanitarian Paradigm of Education

is the feeling of erosion of his/her "I" due to confusion or doubts about the possibility of directing their life in a certain direction.

The Canadian psychologist Marcia (1980) singled out four states or statuses of self-identity: diffuse self-identity, preliminary identification, moratorium, and achieved self-identity.

Research conducted by M. Ginzburg (1996) is also important for pedagogy. When determining the psychological content of personal self-determination, Ginzburg proceeds from the dual nature of the human being. The human is traditionally viewed as a dual spiritual and material being, as the coexistence of spatial-temporal and content-notional aspects. Ginzburg concludes that the spatial-temporal plane is a field of real action (actual and potential) for a person, and the value-notional plane - a field of values and meanings. In his concept, Ginzburg (1994) proposes the following definition of self-determination: personal self-determination is the construction by a person of his/her personal field, which includes both a set of individual life meanings and the space of real action (actual and potential).

In defining the pedagogical foundations for personal self-determination of senior secondary school students, we proceed from the ideas of Vygotsky (1983) that self-determination is a personal new-formation of an individual in adolescence. We also proceed from the "duality" of personal self-determination recognised by all researchers: on the one hand, there is a specific definition of the future profession and planning of life; on the other hand - the search for the meaning of one's existence. Vygotsky singles out three aspects of selfdetermination in adolescence: professional self-determination, personal-selfdetermination, and social self-determination. In this article, we analyse personalself-determination. Vygotsky's conclusion that personal self-determination is a systemic formation that represents the inter-connection and unity of components is very important for pedagogical research. Researchers identify the content and procedural aspects of personal self-determination. In the procedural activity aspect, we focus on the activity cycle developed by Chehlova (Čehlova, 2002).

It seems constructive to consider self-determination as a personal formation, i.e., as a special personality trait. The approach to self-determination as a relatively independent personal formation allows researchers to elucidate this particular formation: its structure, the laws of its formation, as well as psychological and pedagogical factors that contribute to its development. We proceed from the understanding of self-determination as a relatively independent stage of socialization, the essence of which in an individual is the awareness of the purpose and meaning of life, readiness for independent life activity based on correlating one's desires, values and opportunities and requirements set by other people and by society. 


\section{Criteria and Indicators of the Personal Self-determination of Secondary School Students (Content Aspect)}

In this article, we rely on the criteria and indicators of the personal selfdetermination of a senior secondary school student developed in the monograph by M.Chehlov (Čehlovs, 2011).

The content aspect of personal self-determination includes the following criteria and indicators.

Criteria:

1. Value orientations

Indicators:

- Value saturation:

- a wide range of personally significant positive values (life is experienced as meaningful);

- a narrow range of personally significant negative values (life is experienced as meaningless).

2. Meaning of life:

Indicators:

- focus on moral values, moral meaning in life;

- focus on utilitarian-pragmatic values: egoistic meaning. Individual systems of meaning are being formed;

- $\quad$ pragmatic focus;

- $\quad$ existential orientation:

- $\quad$ interest in the meaning of life, active discussions about it, having an existential orientation;

- lack of interest in the meaning of life, lack of existential orientation.

3. Self-concept

Indicators:

- $\quad$ educational competence;

- $\quad$ understanding of one's abilities and capabilities;

- $\quad$ understanding the correspondence of one's abilities and capabilities to the requirements of one's profession;

- $\quad$ objective self-assessment;

- development of self-regulation;

- $\quad$ attitude to oneself as a value;

- $\quad$ attitude to other people as a value;

4. Self-realization

Indicators:

- $\quad$ space for self-realization: wide (broad range of areas of selfrealization), limited (narrow range of areas for self-realization);

- $\quad$ the character of self-realization: creative, reproductive. 
Alijev et al., 2021. Development of the Personal Self-Determination of Secondary School Students in the Context of the Humanitarian Paradigm of Education

\section{Empirical Study}

During the research, there was carried out an establishing experiment. The aim of the experiment was the study of the personal self-determination of a senior secondary school student as a systemic component. In this article, we mainly analyse value orientations using the personal maturity test questionnaire developed by Gilbukh (1995). The experiment was carried out in Riga Classical Gymnasium, involving $3011^{\text {th }}$ and $12^{\text {th }}$ form students, and in Pushkin Lyceum, involving 20 students, in the period of 2018-2019. We used the questionnaires "Your life priorities" and "I am a leader".

\section{Your life priorities \\ Riga Classical Gymnasium}

To have a programme of self-education

To know the diversity of cultures in Latvia

To be active in politics

To participate actively in social life

To know the culture of international.

To know foreign languages

To become an educated person

To be a respected person

To have a lot of friends

To have an interesting job

To help other people

To be free and independent

To be honest and fair...

To create something necessary for society

To have a good family

To become famous

To be a good expert in the chosen profession
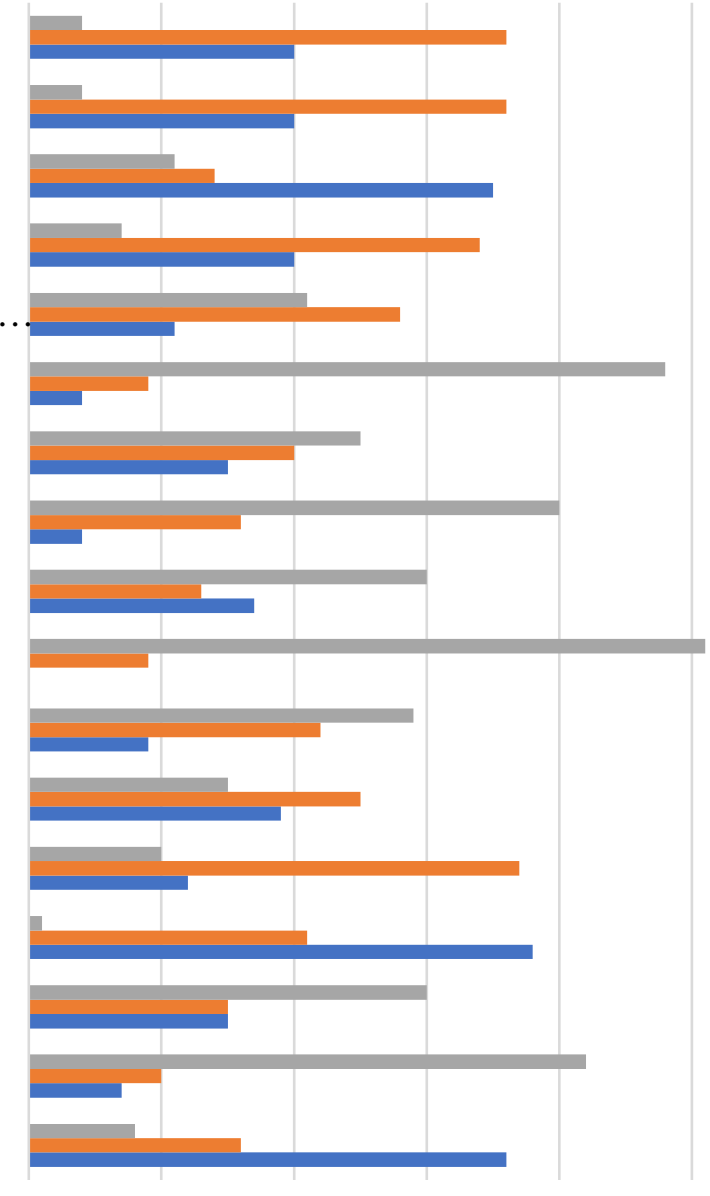

$\begin{array}{llllll}0 & 10 & 20 & 30 & 40 & 50\end{array}$

60

$\square$ High level $\quad$ Intermidiate level $\quad$ Low level

Figure 1 Test “Your life priorities” Riga Classical Gymnasium 
Proceedings of the International Scientific Conference. Volume II, May $28^{\text {th }}-29^{\text {th }}, 2021.63-71$

\section{Your life priorities \\ Pushkin Lyceum}

To have a programme of self-education

To know the diversity of cultures in Latvia

To be active in politics

To participate actively in social life

To know the culture of international. .

To know foreign languages

To become an educated person

To be a respected person

To have a lot of friends

To have an interesting job

To help other people

To be free and independent

To be honest and fair...

To create something necessary for society

To have a good family

To become famous

To be a good expert in the chosen profession
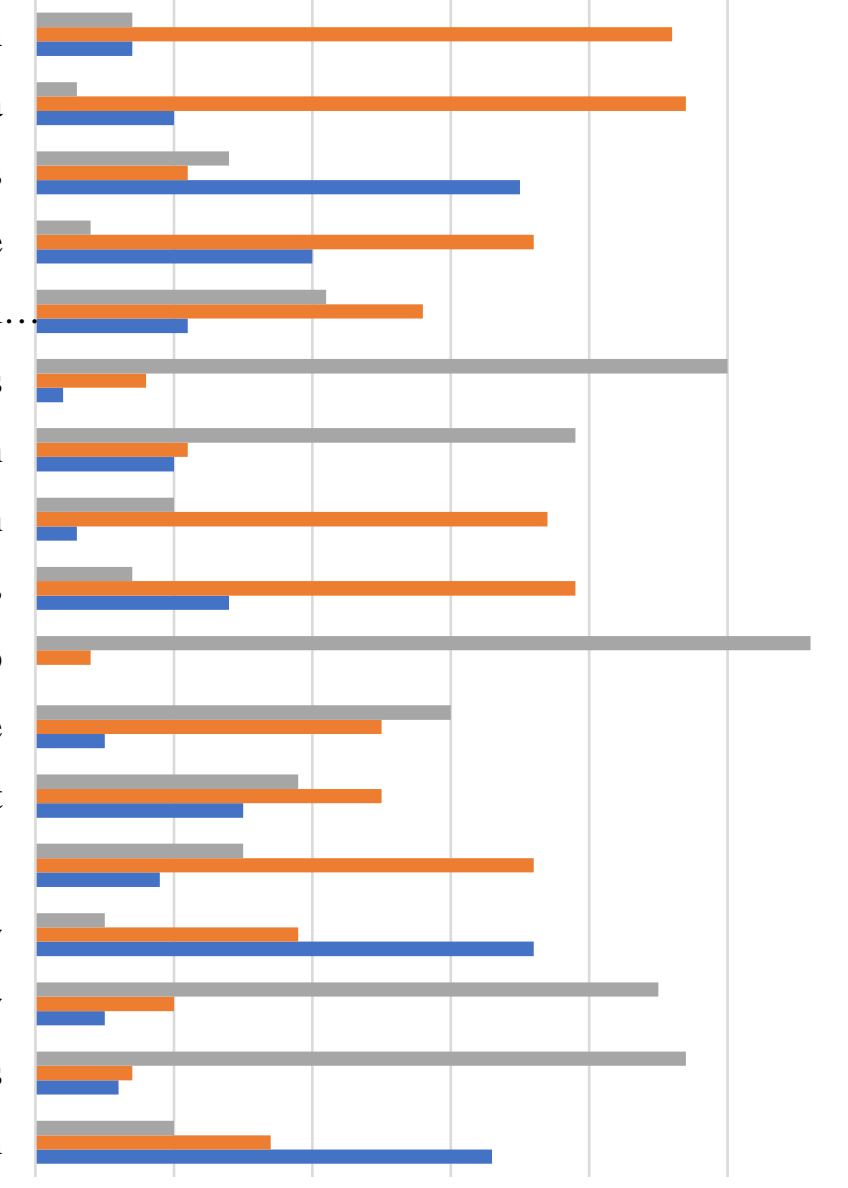

$\begin{array}{llllll}0 & 10 & 20 & 30 & 40 & 50\end{array}$

घhigh level $\quad$ Intermidiate level $\quad$ Low level

Figure 2 Test "Your Life Priorities". Riga Pushkin Lyceum

The analysis of the results of the experiment showed that the structure of personal self-determination of senior secondary school students can be regarded as a system of interrelated components. It was established that the humanitarization of the educational process is the main pre-condition for the development of the personal self-determination of secondary school students both regarding the logic of the subject and the logic of the process of learning (changing the style of relationships), as well as the logic of education (understanding culture as the world of human attitudes and meanings).

The establishing experiment also showed that the personal selfdetermination of secondary school students is characterised by value saturation, but by the focus on utilitarian-pragmatic values. The reason lies in the existence 
Alijev et al., 2021. Development of the Personal Self-Determination of Secondary School Students in the Context of the Humanitarian Paradigm of Education

of objective conditions. It is due to the difficult economic situation in Latvia, as well as in many countries of the world, caused by the pandemic of Covid-19 and the lack of jobs in the chosen speciality. The organization of the educational process based on a knowledge-based approach plays a certain role, as well. Subjective factors also play a significant part, especially, insufficient development of the readiness for personal self-determination and the predominance of interest in material values.

\section{Conclusions}

1. Personal self-determination is a systemic formation representing the interconnection of components.

2. The personal self-determination of a senior secondary school student acquires a moral meaning if the educational process is organised based on the humanitarian paradigm of education.

3. Humanitarization is viewed as a technology of the educational process, where the style of the relationship "teacher-learner" is changing to the relationship "person-person".

4. Culture is seen as the basis for human education.

5. These views became the basis for the humanitarian paradigm of education developed by Chehlov (Čehlovs, 2011).

6. The experimental study of the value orientations of secondary school students, the systemic component of personal self-determination showed that personal self-determination is characterised by value saturation; at the same time, there can be observed focus on utilitarian-pragmatic values.

\section{References}

Alijevs, R. (2005). Izglītības filosofija 21. gadsimts. Rīga: Retorika A.

Čehlova, Z. (2002). Izziñas aktivitāte mācībās. Rīga: RAKA.

Čehlova, Z. (2001). Kognitīvie attīstošie didaktiskie modeḷi studijās. Vispārī̄gā didaktika un audzināšana. Rīga: LU Akadēmiskais apgāds.

Čehlovs, M. (2011). Vidusskolēnu pašnoteikšanās attīstības humanitārie aspekti. Rīga: RAKA.

Chehlova, Z., Chehlov, M., \& Gode, I. (2018). The methodology of the development of competency-based approach in pedagogy. Society. Integration. Education. Proceedings of the International Scientific Conference, (2). Rezekne: Rezekne Academy of Technologies, 93-102.

Chehlova, Z., Kevisa I., Chehlov, M., \& Marchenoka, M. (2016). The Civic Self-Awareness of Senior Secondary School Students in the Context of Globalization. Il Nodo -per una pedagogia della persona. No 47, 56-67.

Erikson, E. (1959). Identity and the life cycle: Selected papers. New York: International Universities Press. 

Proceedings of the International Scientific Conference. Volume II, May $28^{\text {th }}-29^{\text {th }}$, 2021. 63-71

Marcia, J. (1980). Identity in adolescence. In: J. Adelson (ed.) Handbook of adolescent psychology (pp.213-231). New York: John Willey.

Gilbukh, J. (1995). Test-oprosnik lichnostnoi zrelosti. Kiiv.

Ginzburg, M. (1996). Psihologija lichnostnogo camoopredelenija: Avtoref. dokt. psihol. Nauk. Moskva: Pedagogika.

Ginzburg, M. (1994). Psihologicheskoe soderzhanie lichnostnogo samoopredelenija Voprosy psihologii, (3). Moskva: Prosveschenie.

Rubinstein, S. (1989). Osnovy obschej psihologii. Moskva: Vlados.

Vygotsky, L. (1983). Istorija razvitija vysshyh psihicheskih funkcij. Sobr.soch. v 6 t., (3). Moskva: Pedagogika. 